\title{
KEEFEKTIFAN PENERAPAN METODE SIMULASI DALAM PEMBELAJARAN EKONOMI (EKSPERIMEN PADA SISWA KELAS $X$ SMA LABORATORIUM UM TAHUN AJARAN 2012-2013)
}

\author{
Ni'matul Istiqomah \\ Program Studi Pendidikan Ekonomi, Program Pascasarjana \\ Universitas Negeri Malang \\ Malang, Indonesia \\ e-mail: neima isti311@yahoo.co.id
}

\begin{abstract}
Abstrak
Tujuan penelitian ini adalah untuk mengetahui keefektifan metode pembelajaran simulasi dengan metode penelitian eksperimen untuk menguji efektifitas metode simulasi dan sebagai pembanding digunakan kelas kontrol metode mind mapping dan inquiry. Teknik analisis data yang digunakan adalah kuantitatif yaitu untuk mengetahui interaksi antara metode, economic literacy dan gaya belajar serta menggunakan statistik analisis varian dengan variabel moderator economic literacy dan gaya belajar. Berdasarkan hasil penelitian menunjukkan bahwa ada perbedaan rata-rata hasil belajar siswa dimana siswa yang belajar dengan menggunakan metode simulasi memiliki rata-rata hasil belajar lebih tinggi dengan gain score sebesar 25.581. Selain itu, hasil Tests of Between-Subjects Effects $0,033<0,05$ menunjukkan terdapat interaksi antara metode, economic literacy dan gaya belajar siswa.
\end{abstract}

Kata Kunci: economic literacy, gaya belajar, hasil belajar, inquiry, mind mapping.

\begin{abstract}
The purpose of this research is to know the effectiveness of simulation learning methods with experimental research methods to test the effectiveness of the methods of simulation and comparison of control class methods use mind mapping and inquiry. Data analysis technique used is to know the quantitative interactions between methods, economic literacy and learning style and use statistical analysis variant with variable moderator economic literacy and learning style. Based on research shows that there is a difference between the average results of student learning where students who learn by using simulation methods have on average higher learning outcomes with gain score of 25.581. In addition, the results of the Tests of Between-Subjects Effects $0,033<0,05$ suggests there is interaction between the methods, economic literacy and learning styles of students.
\end{abstract}

Keywords: economic literacy, learning styles, learning outcomes, inquiry, mind mapping. 


\section{PENDAHULUAN}

Pendidikan memegang peranan penting dalam mepersiapkan sumberdaya manusia bagi kehidupan di masa yang akan datang. Melalui proses belajar diharapkan akan tercapai tujuan pembelajaran. Tujuan pembelajaran dapat tercapai jika siswa melibatkan dirinya secara aktif dalam kegiatan belajar baik fisik, mental, maupun emosional. Apabila dikaji lebih lanjut, tujuan pendidikan bukan hanya menuntut siswa untuk mendapatkan output yang tinggi namun bagaimana pendidikan tersebut dapat mengembangkan manusia yang dirumuskan dalam Undang-undang No. 20 tahun 2003 yang bebunyi:

"Pendidikan nasional diselenggarakan dengan tujuan untuk mencerdaskan kehidupan bangsa dan mengembangkan manusia Indonesia seutuhnya, yaitu manusia yang beriman dan bertakwa terhadap Tuhan Yang Maha Esa, memiliki pengetahuan dan keterampilan, kesehatan jasmani dan rohani, kepribadian yang mantap dan mandiri, serta rasa tanggung jawab kemasyarakatan dan kebangsaan."

Berdasarkan hal tersebut, maka pendidikan hendaknya dapat lebih mengutamakan bagaimana pencapaian hasil dengan mengambangkan segala potensi yang terdapat dalam diri manusia. Keberhasilan siswa dalam belajar dapat dilihat dari hasil belajar atau evaluasi belajar siswa tersebut. Hasil belajar siswa yang tinggi akan memberikan dorongan dan semangat siswa meningkatkan minat belajar terhadap mata pelajaran, karena minat merupakan sesuatu yang sangat penting bagi seseorang dalam melakukan suatu kegiatan. Kebiasaan dan karakteristik belajar siswa juga merupakan salah satu faktor yang mempengaruhi keberhasilan siswa dalam pencapaian hasil belajar diluar faktor kemampuan dasar siswa.

Selain kemampuan dasar siswa, jalannya pembelajaran yang diterapkan oleh guru di kelas juga akan mempengaruhi emosional dan minat belajar siswa. Pemilihan metode pembelajaran menjadi salah satu faktor bagaimana pembelajaran yang kondusif. Berdasarkan hasil wawancara dan observasi, fenomena pemilihan metode pembelajaran yang kurang sesuai ini juga terjadi di Sekolah Menengah Atas (SMA) Laboratorium UM. Pemilihan metode konvensional yang kerap kali diterapkan guru tidak selalu berdampak buruk terhadap hasil belajar, akan tetapi dapat mempengaruhi minat siswa dalam belajar.

Mata pelajaran ekonomi merupakan mata pelajaran yang pada dasarnya lebih kepada pengalaman ekonomi sehari-hari siswa. Berdasarkan pengalaman yang siswa peroleh sehari-hari tersebut maka pemilihan metode simulasi akan menjadi efektif pada materi inflasi di kelas $X$. Selain itu, untuk mengetahui bagaimana kemampuan dasar ekonomi siswa, diukur pula bagaimana tingkat kemampuan economic literacy. Dalam kegiatan belajar siswa, setiap siswa memiliki karakteristik belajar yang berbeda-beda sehingga pencapaian hasil belajar ini juga dipengaruhi oleh gaya belajar dari masing-masing siswa.

Berdasarkan latar belakang tersebut maka peneliti berupaya untuk menerapkan metode belajar simulasi untuk diuji efektifitasnya dengan menyajikan kelas kontrol dengan menggunakan metode belajar mind mapping dan inquiry. Selain itu, peneliti 
mengelompokkan hasil belajar siswa dengan tingkat economic literacy dan gaya belajar siswa.

Tujuan dari penelitian ini adalah untuk menguji efektifitas hasil belajar siswa yang diajar menggunakan metode simulasi, mind mapping dan inquiry. Selain itu peneliti akan melihat apakah terdapat interaksi antara metode pembelajaran, tingkat economic literacy dan gaya belajar siswa dengan menggunakan bantuan statistika analisis varian.

\section{METODE}

Penelitian ini dirancang dengan menggunakan rancangan penelitian eksperimantal semu (quasi experimental design). Rancangan penelitian eksperimental semu bertujuan untuk menguji pengaruh variabel-variabel bebas terhadap variabel terikat. Menurut Tuckman (1978:133) berpendapat bahwa rancangan desain faktorial adalah memodifikasi penelitian eksperimen dengan komplikasi lebih lanjut bahwa variabel bebas (biasanya variabel moderator) tambahan yang disertakan selain variabel perlakuan. Pada penelitian ini, terdapat dua variabel moderator yakni economic literacy dan gaya belajar siswa.

Penelitian

eksperimen

ini

menggunakan desain eksperimental faktorial $3 \times 3$ berarti variabel pertama memiliki 3 tingkatan dan variabel kedua mempunyai 3 tingkatan. Makna dari desain tersebut yaitu, pada variabel pertama merupakan model pembelajaran terdiri dari tiga model pembelajaran yaitu inquiry, simulasi, dan mind mapping. Variabel kedua merupakan hasil belajar. Variabel moderator pertama menggunakan kemampuan economic literacy siswa dengan tingkatan tinggi, sedang, dan rendah. Variabel moderator kedua adalah gaya belajar siswa yang terdiri atas concrete sequential, abstract sequential, concrete random, dan abstract random. Pemilihan desain penelitian ini mengacu pada referensi yang dikemukakan oleh Gay. L (2006:261) tentang randangan desain faktorial.

Instrumen pengumpulan data menggunakan tes dan angket. Tes digunakan untuk mengetahui bagaimana tingkat kemampuan economic literacy siswa dan tes untuk mengetahui hasil belajar siswa. Kedua instrumen tes berupa soal tersebut sebelumnya telah diuji bagaimana validitas, reliabilitas, daya pembeda, dan tingkat kesulitasn soal. Sedangkan untuk angket digunakan untuk mengetahui bagaimana kecenderungan gaya belajar siswa. Selanjutnya terdapat panduan wawancara dan observasi untuk mengetahui bagaimana keberhasilan guru dalam menerapkan metode pembelajaran.

Analisis data yang digunakan adalah analisis varian yang digunakan untuk mengatasi perbedaan nilai variabel terikat yang dikategorikan berdasarkan variabel bebas yang banyak dan masingmasing terdiri dari beberapa kelompok. Pengujian hipotesis dilakukan dengan taraf signifikansi $5 \% \quad(\alpha=0.05)$. Sebelum dilakukan analisis varian data sebelumnya telah lulus uji prasyarat analisis yaitu uji normalitas dan homogenitas.

\section{HASIL DAN PEMBAHASAN}

Identifikasi tingkat economic literacy digunakan untuk mengetahui tingkat kemampuan economic literacy siswa, apakah siswa tersebut termasuk kedalam 
kategori tingkat economic literacy tinggi, sedang, atau rendah. Tabulasi data

tingkat economi literacy siswa dapat dilihat pada tabel dibawah ini.

Tabel 1. Tabulasi data tingkat economi literacy

\begin{tabular}{lccc}
\hline Kelas & \multicolumn{3}{c}{ Tingkat Economic literacy } \\
\cline { 2 - 4 } & Tinggi & Sedang & Rendah \\
\hline Simulasi & 14 & 17 & 12 \\
Mind mapping & 9 & 20 & 15 \\
Inquiry & 12 & 21 & 10 \\
\hline
\end{tabular}

Identifikasi gaya belajar ini bertujuan untuk mengetahui gaya belajar masing-masing siswa. Apakah siswa tersebut termasuk ke dalam kategori siswa dengan kecenderungan gaya belajar Concrete Sequential, Abstract Sequential, Concrete Random, atau Abstract Random. Tabulasi gaya belajar siswa dapat dilhat dalam tabel dibawah ini.

Tabel 2. Tabulasi gaya belajar siswa

\begin{tabular}{lcccc}
\hline \multirow{2}{*}{ Kelas } & \multicolumn{5}{c}{ Gaya Belajar Siswa } \\
\cline { 2 - 5 } & CS & AS & CR & AR \\
\hline Simulasi & 5 & 14 & 5 & 22 \\
Mind mapping & 8 & 6 & 7 & 23 \\
Inquiry & 14 & 6 & 8 & 13 \\
\hline
\end{tabular}

Pada penelitian ini terdapat empat hipotesis yang akan diuji. Hipotesis 1-3 menggunakan analisis paired samples test yakni pengujian untuk mengetahui perbedaan rata-rata hasil belajar siswa yang belajar menggunakan metode simulasi, mind mapping, dan inquiry. Sedangkan hipotesis keempat adalah untuk menguji interaksi antara metode pembelajaran, economic literacy, dan gaya belajar.

Pengujian hipotesis 1, perbedaan rata-rata hasil belajar siswa yang belajar menggunakan metode simulasi. Pada penghitungan statistik menggunakan SPSS 16.0 for windows diperoleh tingkat signifikansi 0.000 dan nilai $t$ sebesar 14.712. Dari penghitungan tersebut diperoleh hasil gain score sebesar 25.581 menunjukkan bahwa terjadi peningkatan dari hasil belajar awal dan hasil belajar siswa setelah diterapkan pembelajaran simulasi. Jadi dapat disimpulkan bahwa rata-rata nilai post test dan nilai post test pada pembelajaran simulasi lebih baik dari kemampuan awal siswa dengan kata lain model pembelajaran simulasi memberikan pengaruh terhadap hasil belajar siswa. Hal ini serupa dengan penelitian yang dilakukan oleh Sandi (2013).

Pengujian hipotesis 2, perbedaan rata-rata hasil belajar siswa yang belajar menggunakan metode mind mapping. Hipotesis ke-2 ini untuk mengetahui perbedaan rata-rata hasil belajar siswa yang belajar menggunakan metode mind mapping. Penghitungan dilakukan dengan menggunakan SPSS dan analisis paired samples test untuk mengetahui seberapa besar gain score yang diperoleh. Hasil statistik menunjukkan 
bahwa tingkat signifikansi sebesar 0.000 dan nilai t untuk post test sebesar 10.179. Dapat disimpulkan bahwa rata-rata nilai post test pada pembelajaran mind mapping memiliki perbedaan yang signifikan. Diperoleh hasil gain score sebesar -18.409 dengan nilai hasil akhir yang lebih tinggi dari nilai awal. Dengan demikian hasil belajar siswa pada pembelajaran mind mapping memberikan pengaruh terhadap hasil belajar siswa.

Pengujian hipotesis 3 , perbedaan rata-rata hasil belajar siswa yang belajar menggunakan metode inquiry. Berdasarkan hasil pengujian hipotesis 3 dengan menggunakan SPSS 16.00 . Dari hasil analisis uji beda $t$-test terlihat pada tabel paired samples test nilai t untuk post test adalah sebesar 12.664 dengan probabilitas 0.000 (2-tailed). Jadi dapat disimpulkan bahwa rata-rata nilai post test dan post test pada pembelajaran inquiry memiliki perbedaan yang signifikan. Diperoleh gain score sebesar 16.163 dengan nilai akhir yang lebih tinggi dari nilai awal. Pada pengujian hipotesis ke-3 ini hasil belajar siswa meningkat setelah adanya perlakuan dengan menggunakan pembelajaran inquiry. Hal ini terlihat terdapat perbedaan dari pencapaian tes awal dan tes akhir siswa.

Dari pengujian ketiga hipotesis tersebut dapat dilihat bahwa perbedaan hasil belajar dari gain score yang diperolah. Hasil belajar siswa dengan menggunakan metode simulasi lebih tinggi. Hasil belajar rata-rata siswa pada kelas simulasi lebih tinggi daripada kelas inquiry dan mind mapping.

Pengujian Hipotesis 4, ada perbedaan hasil belajar yang menggunakan metode pembelajaran simulasi, mind mapping, dan inquiry melalui tingkat economic literacy dan gaya belajar

Berdasarkan hasil uji Anova 3 jalur yang dapat dilihat pada tabel 3 untuk pengujian hipotesis 4 dan menggunakan program SPSS 16 for windows menunjukkan bahwa terdapat pengaruh langsung antara variabel independen metode pembelajaran terhadap hasil belajar siswa. Metode pembelajaran memberikan nilai $F$ sebesar 10.746 dan signifikansi pada 0,05 hal ini menunjukkan bahwa terdapat perbedaan hasil belajar antara siswa yang diajar menggunakan metode simulasi, inquiry, dan mind mapping. Hal ini berarti metode mempengaruhi hasil belajar kognitif siswa.

Tingkat Economic literacy (EL) memberikan nilai $F$ sebesar 6.204 dan signifikansi kurang dari 0,05 yang menunjukkan terdapat perbedaan hasil belajar siswa pada tingkat kemampuan economic literacy siswa terhadap hasil belajar siswa. Gaya belajar siswa menunjukkan nilai $F$ sebesar 3.633 dengan signifikansi sebesar 0,016 yang lebih kecil dari 0,05 menunjukkan bahwa terdapat perbedaan hasil belajar berdasarkan gaya belajar siswa. 
Tabel 3. Hasil pengujian Anova $\mathbf{3}$ jalur

Tests of Between-Subjects Effects

Dependent Variable:HasilBelajar

\begin{tabular}{|c|c|c|c|c|c|}
\hline Source & $\begin{array}{l}\text { Type III Sum of } \\
\text { Squares }\end{array}$ & $\mathrm{df}$ & Mean Square & $\mathrm{F}$ & Sig. \\
\hline Corrected Model & $1828.432^{\mathrm{a}}$ & 34 & 53.777 & 3.611 & .000 \\
\hline Intercept & 497792.645 & 1 & 497792.645 & 3.343E4 & .000 \\
\hline Metode & 320.034 & 2 & 160.017 & 10.746 & .000 \\
\hline EL & 184.782 & 2 & 92.391 & 6.204 & .003 \\
\hline GayaBelajar & 162.315 & 3 & 54.105 & 3.633 & .016 \\
\hline Metode * EL & 268.975 & 4 & 67.244 & 4.516 & .002 \\
\hline Metode * GayaBelajar & 301.099 & 6 & 50.183 & 3.370 & .005 \\
\hline EL * GayaBelajar & 275.260 & 6 & 45.877 & 3.081 & .008 \\
\hline $\begin{array}{l}\text { Metode } \\
\text { GayaBelajar }\end{array}$ & 332.617 & 11 & 30.238 & 2.031 & .033 \\
\hline Error & 1429.583 & 96 & 14.891 & & \\
\hline Total & 795900.000 & 131 & & & \\
\hline Corrected Total & 3258.015 & 130 & & & \\
\hline
\end{tabular}

a. $\mathrm{R}$ Squared $=.561$ (Adjusted R Squared $=.406$ )

Sedangkan hasil interaksi dari variabel metode, economic literacy, dan gaya belajar siswa juga terlihat dalam tabel. Interaksi antara metode dan economic literacy (Metode* $\mathrm{EL}$ ) memberikan nilai $F$ sebesar 4.516 dan signifikansi pada 0,05 hal ini menunjukkan ada perbedaan hasil belajar sebagai interaksi metode pembelajaran terhadap economic literacy. Hasil interaksi antara metode dan gaya belajar (Metode*GayaBelajar) siswa memberikan nilai $F$ sebesar 3.370 dan signifikansi pada 0,05 hal ini menunjukkan bahwa terdapat perbedaan hasil belajar sebagai akibat interaksi metode dan gaya belajar siswa. Interaksi antara metode, economic literacy dan gaya belajar siswa (Metode*EL*GayaBelajar) memberikan nilai $F$ sebesar 2.031 dan signifikansi terhadap
0,05 hal ini menunjukkan bahwa terdapat perbedaan hasil belajar sebagai akibat interaksi metode pembelajaran, tingkat economic literacy, dan gaya belajar siswa. $R$ Squared sebesar $56,1 \%$ berarti berarti interaksi hasil belajar yang dapat dijelaskan oleh metode pembelajaran, economic literacy, gaya belajar dan interaksi antara metode pembelajaran, economic literacy, dan gaya belajar siswa sebesar $56,1 \%$.

Pada penerapan ketiga metode penelitian pada siswa kelas $X$ SMA Laboratorium UM, penerapan metode simulasi efektif diterapkan pada materi inflasi. Untuk tingkat kemampuan economic literacy siswa, siswa dengan kemampuan economic literacy mencapai hasil belajar tinggi pada kelas simulasi. Hal ini dikarenakan siswa telah memiliki dasar kemampuan ekonomi sehingga 
memudahkan siswa untuk memahami pelajaran ekonomi. Untuk pengaruh terhadap gaya belajar, siswa dengan kecenderungan gaya belajar abstract random mencapai hasil belajar lebih tinggi pada kelas simulasi. Hal ini dikarenakan bahwa siswa dengan kecenderungan gaya belajar abstract random memiliki ciri spontan dan nyata. Dengan penerapan metode simulasi, siswa dengan kecenderungan belajar ini dapat memaksimalkan kemampuannya untuk melakukan simulasi dan bagi siswa dengan gaya belajar ini metode simulasi merupakan hal yang baru dan siswa dengan gaya belajar ini sangat menyukai hal baru.

Interaksi dari metode pembelajaran, tingkat economic literacy, dan gaya belajar menurut uji anova manunjukkan terdapat interaksi terhadap hasil belajar kognitif siswa. Metode pembelajaran simulasi memberikan hasil belajar lebih tinggi dibandingkan dengan metode pembelajaran lain yaitu mind mapping dan inquiry. Tingkat economic literacy yang tinggi berpengaruh terhadap pencapaian gaya belajar siswa. Siswa dengan kemampuan economic literacy tinggi akan memperoleh hasil belajar tinggi. Sedangkan gaya belajar siswa menunjukkan karakteristik belajar yang sesuai dengan metode pembelajaran yang diterapkan.

\section{SIMPULAN DAN SARAN}

Kesimpulan pada hipotesis pertama adalah ada perbedaan rata-rata hasil belajar pada penerapan metode pembelajaran simulasi melalui tingkat economic literacy dan gaya belajar siswa. Berdasarkan uji hipotesis dengan tingkat signifikansi 0,05 dan gain score diketahui bahwa hasil belajar siswa dengan menggunakan metode pembelajaran simulasi lebih tinggi dan terdapat peningkatan hasil belajar siswa setelah diterapkan metode pembelajaran simulasi.

Hipotesis kedua dapat disimpulkan bahwa ada perbedaan rata-rata hasil belajar penerapan pada pembelajaran mind mapping melalui tingkat economic literacy dan gaya belajar siswa. Berdasarkan uji hipotesis terdapat perbedaan rata-rata hasil belajar kognitif siswa setelah diterapkan pembelajaran mind mapping.

Hipotesis ketiga dapat disimpulkan bahwa ada perbedaan rata-rata penerapan metode pembelajaran inquiry melalui tingkat economic literacy dan gaya belajar siswa. Berdasarkan uji hipotesis terlihat gain score sebesar 16.163 yang berarti menunjukkan bahwa terdapat perbedaan hasil belajar kognitif siswa saat diterapkan metode pembelajaran inquiry.

Pada hipotesis ketempat dapat disimpulkan bahwa ada perbedaan hasil belajar simulasi, mind mapping, dan inquiry melalui tingkat economic literacy dan gaya belajar siswa. Hal ini terlihat dari hasil post test dan gain score yang diperoleh masing-masing model pembelajaran yang berbeda. Model pembelajaran simulasi melalui economic literacy dan gaya belajar memiliki gain score tertinggi sebesar -25.581 , kemudian diikuti oleh metode pembelajaran mind mapping melalui tingkat economic literacy dan gaya belajar yang memiliki gain score sebesar 18.409, dan yang terakhir penerapan metode pembelajaran inquiry yang memiliki gain score -16.163.

Saran untuk pemanfaatan dalam pembelajaran ekonomi adalah untuk 
pembelajaran ekonomi yang inovatif, disarankan menggunakan metode pembelajaran simulasi pada siswa dengan kemampuan economic literacy tinggi dan kecenderungan gaya belajar abstract random. Selain itu, dapat disosialisasikan tentang metode-metode pembelajaran inovatif seperti simulasi, mind mapping, dan inquiry sehingga pengetahuan guru tentang metode pembelajaran dapat diimplementasikan dalam kegiatan belajar mengajar di kelas. Dalam pembelajaran di kelas, setiap guru diharapkan mengetahui bagaimana gaya belajar siswa sehingga dapat dimaksimalkan tentang metode yang akan diterapkan.

Saran untuk penelitian lebih lanjut adalah dalam penelitian lebih lanjut dengan model penelitian yang sama, perlu dikaji tentang metode-metode pembelajaran yang tidak hanya terpaku pada guru, namun perlu diintegrasikan pembelajaran yang mengacu pada student centre. Untuk lebih memperkaya kajian empiris, maka perlu dikaji faktor apa saja yang mempengaruhi hasil belajar, tidak hanya tingkat kemampuan economic literacy maupun gaya belajar namun dapat dikaji dengan variabel lain.
Untuk pengukuran hasil belajar, dapat diperkaya dengan mengukur hasil belajar afektif maupun psikomotor siswa.

\section{DAFTAR PUSTAKA}

Gay, L. R. dkk. 2006. Educational Research Competencies for Analysis and Application. Ohio: Upper Saddle River, New Jersey Colombus

Sandi. 2013. Efektivitas Penerapan Strategi Pembelajaran Kooperatif Kolaborasi Think Pair Share dengan Simulasi dalam Pembelajaran Ekonomi terhadap Hasil Belajar Siswa (Studi Eksperimen pada Siswa di SMP Negeri 5 Probolinggo). Tesis tidak diterbitkan. Malang: PPS Universitas Negeri Malang.

Tuckman, B, W. 1978. Conducting Education Research (Second Edition). New York: Harcourt Brace Jovanovich, Publiser.

Undang-Undang Republik Indonesia Nomor 20 Tahun 2003 tentang Sistem Pendidikan Nasional. 2003. Bandung: Citra Umbara. 